\begin{tabular}{c}
\hline JMEMME, 2 (1) June $2018 \quad$ p-ISSN: 2549-6220e-ISSN: 2549-6239 \\
JOURNAL OF MECHANICAL ENGINEERING, \\
MANUFACTURES, MATERIALS AND ENERGY \\
Available online http://ojs.uma.ac.id/index.php/jmemme
\end{tabular}

\title{
Numerical Study on Plate Holders Pipe Recovery Boiler Superheater
}

\author{
Amrinsyah*, Amir Syam, Darianto, Zulfikar \\ Mechanical Engineering Dept., Univ. Medan Area, Indonesia \\ *Corresponding author: E-mail: amrin_syah56@yahoo.com
}

\begin{abstract}
Abstrak
Bagian penting yang berfungsi sebagai penahan superheater header pada jenis boiler Recovery (RB) ialah sepasang plat penahan yang digantungkan pada batang gantungan. Bagian ini sangat sulit dianalisa secara eksperimental karena terdapat bahan isolasi yang tebal dan kondisi kerja yang berat. Penelitian ini bertujuan untuk mendapatkan distribusi tegangan yang terjadi pada plat sebagai efek beban statik dengan mode simulasi. Model dirancang berdasarkan ukuran sebenarnya, yaitu 400 x $200 \mathrm{~mm}$ dengan ketebalan $15 \mathrm{~mm}$. Simulasi ini menggunakan software FEM Ansys versi 5.4. Teori analisa kegagalan Tresca dan von Mises menjadi rujukan untuk kekuatan bahan. Teori kontak area yang diwakili b ditujukan untuk menentukan panjang area tegangan sepanjang kurva dari kedua kontak area. Bahan yang digunakan ialah dari baja ASTM A514 dengan kekuatan luluh $690 \mathrm{MPa}$. HAsilnya adalah distribusi tegangan sepanjang kurva dan juga titik kritis dimana memiliki kemungkinan kegagalan terjadi pada plat penahan. Hasil analisa dapat menjadi referensi untuk pengembangan konstruksi lebih lanjut.
\end{abstract}

Kata kunci: Analisa Kegagalan, Area Kontak, Plat Pendukung, Simulasi Numerik

\begin{abstract}
The important part which has a function as supporting of superheater header on the boiler recovery type $(R B)$ is a couple of support plate which is hanged on the hanger rod. This part is very difficult to analyze by experimental because there are in a tight insulation and heavy duty condition. This research aim to obtain the stress distribution that happened on the plate as the effect of static load in simulation mode. The model is designed base on the dimension of real support plate size $400 \times 200 \mathrm{~mm}$ and thickness $15 \mathrm{~mm}$. It is use the FEM software of Ansys version 5.4. The theory of failure analysis of Tresca and von Mises become the reference for materials strength. The area contact theory of $b$ represents the reference to determine the length of stress area along curve of both contact area. The material that is used is from steel ASTM A514 with the yield strength $690 \mathrm{MPa}$. The Result is stress distribution along curve and also critical point which has possibility failure occurs on the support plate. The analysis result could be a reference for the development of the further construction.
\end{abstract}

Keywords: Support Plate, Simulation, Failure Analysis, Contact Area.

How to Cite: Amrinsyah (2018), Numerical Study on Plate Holders Pipe Recovery Boiler Superheater, JMEMME (Journal Of Mechanical Engineering, Manufactures, Materials And Energy), 2 (1): 27-32 


\section{Amrinsyah, Numerical Study on Plate Holders Pipe Recovery Boiler Superheater}

\section{INTRODUCTION}

The most important part to hold the weight of Superheater on Boiler Recovery type is a pair of plates hung through a hanger rod and bound by two pins. Pins and plates are not permanently tied, but only loose and flexible so as to hold the weight at once can overcome the load in the axial direction. To maintain stability during operation, usually at the end of the pin is given a ring that is connected through the point weld ( Yasniy, Pyndus, Brevus, Iasnii, \& Lapusta, 2016). The location of these sections is just above the combustion chamber with a very high working temperature.

Stress distribution that occurs on the plate is very difficult once determined experimentally. This is due to the difficulty of retrieving test data with the position of the element is at a height up to reach more than $80 \mathrm{~m}$ from the ground floor and also covered a very thick insulation material (Barma, et al., 2017). Therefore, one of the best methods to get stress distribution in a particular location is to use a numerical simulation method (Sankar, Rao, Seshadri, \& Balasubramanian, 2016) (Taler, Trojan, Dzierwa, Kaczmarski, \& Taler, 2018).

Failure on the type of ductile material may occur when the maximum shear stress is equal to or exceeds the maximum shear stress value in a test of the material (Shokouhmand, Ghadimi, \& Espanani, 2015). Thus, when associated with main stress on a mechanical element, the failure of a material will occur when $\sigma_{1}$ and $\sigma_{3}$ have exceeded the tensile stress. When viewed from the amount of distortion energy that occurs, the material failure will occur when the strain energy distortion per unit volume reaches or exceeds the strain energy distortion per unit volume in a tensile or compression test on the same material. This theory is also known as the von Mises theory. In other words, failure of ductile material will occur if von Mises stress $(\sigma ')$ reaches or exceeds its tensile stress (Sy).

If it is considered that the normal stress section on each surface is equal to the hydrostatic stress $\left(\sigma_{\mathrm{Av}}\right)$, then there will be eight symmetrical surfaces in the main direction that will be subjected to the stress. Failure is expected to occur when the octahedral shear stress at each section undergoing stress equals or exceeds the octahedral shear stress in a simple tensile test of a test specimen to failure. This is similar to the prediction of a material failure based on the theory of distorted energy, where the shear stress that can cause failure occurs when the shear stress reaches up to $57.7 \%$ of the tensile stress of the material (Shokouhmand, Ghadimi, \& Espanani, 2015).

When the surface of two objects that have a shape like the curves touching each other, then the contacts that occur at the point and the line will turn into contact area ( Tavares, et al., 2014). The stress that occurs will also evolve from two dimensional models into three dimensions.

The contact area of the two cylindrical portions with a thickness of $\mathrm{l}$, the diameter of the first part $\mathrm{d} 1$ and the second part $\mathrm{d} 2$ is denoted by $2 \mathrm{~b}$, as shown in Figure 1 . The stress that occurs in the contact area consists of the normal stresses in the direction of the $\mathrm{x}$ axis $\left(\sigma_{\mathrm{x}}\right)$ and $\mathrm{y}\left(\sigma_{\mathrm{y}}\right)$, and the principal stress $\sigma_{3}$. For $0 \leq \mathrm{z} \leq 0.436 \mathrm{~b}$, then $\sigma_{1}=\sigma_{\mathrm{x}}$, and $\sigma_{\max }=\left(\sigma_{1}-\sigma_{3}\right) / 2=\left(\sigma_{\mathrm{x}}-\right.$ $\left.\sigma_{\mathrm{z}}\right) / 2$. For $\mathrm{z} \geq 0.436 \mathrm{~b}$, then $\sigma_{1}=\sigma_{\mathrm{y}}$, and $\sigma_{\max }$ $=\left(\sigma_{\mathrm{y}}-\sigma_{\mathrm{z}}\right) / 2$. 
This study aims to obtain the amount of nodal displacement and stress distribution that occurs on the superheater holder plate. The results of this simulation will be useful to provide information to the manufacturer so that it can produce a better design and safe.

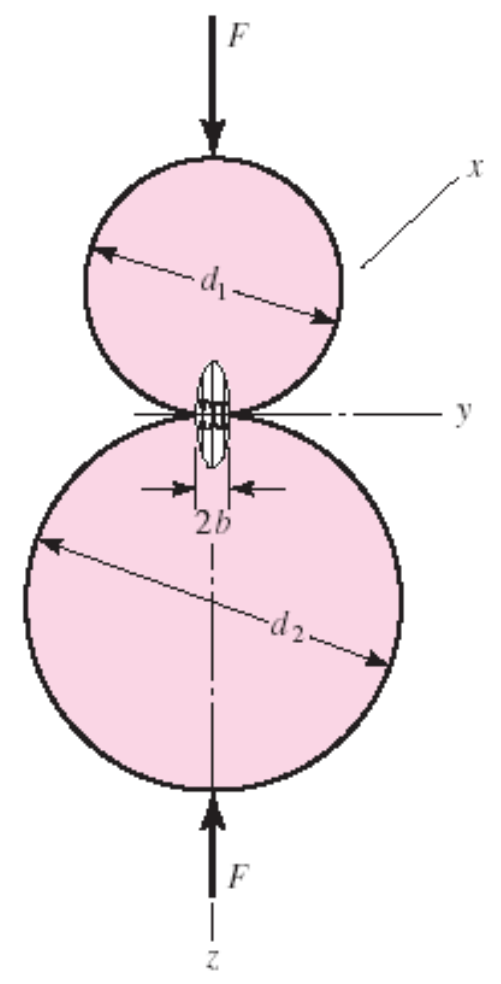

Figure 1. Area cotact $2 b$

\section{METHODOLOGY}

The superheater recovery boiler plate form is shown in Fig. 2. Design of plate holder model is done by using software ANSYS 5.4 with size $400 \times 200 \times 15 \mathrm{~mm}$. The model designs in this study begin at the starting point of the work sheet coordinates in WP X, Y $(0,0)$, width 200 $\mathrm{mm}$, and height $400 \mathrm{~mm}$. This modeling step is done on the Preprocessor menu, as shown in Figure 3.

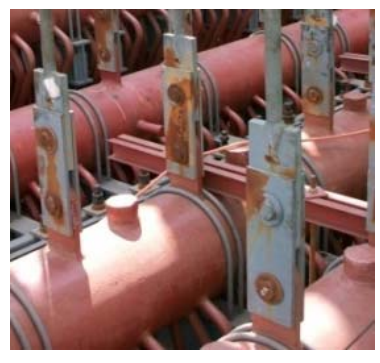

Figure 2. Superheater plate holder

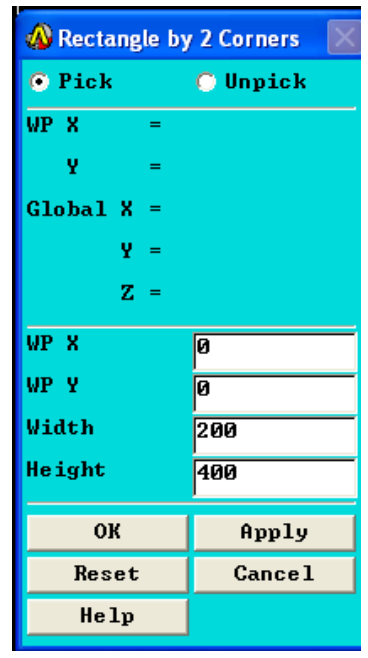

Figure 3. 2D object modeling

In the model are given 2 (two) holes with a diameter of $50 \mathrm{~mm}$ at the distance WP X, Y $(100,300)$. Then the model is given a pin hole with subtract method so that obtained model plate holder that has been equipped with hole pin as shown in Figure 4. 


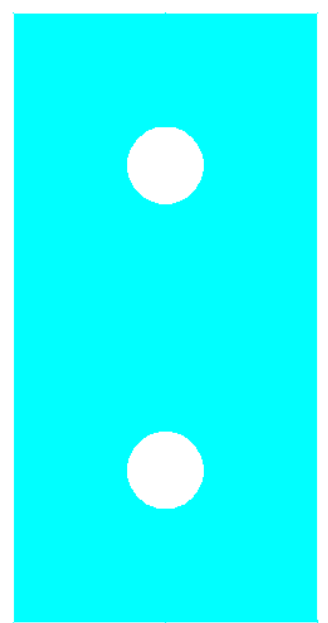

Figure 4. Model holder plate that has been given pin hole

Type of material used for this plate is ASTM A514 high strength alloy steel with tensile strength $690 \mathrm{MPa}$, density 7800 $\mathrm{kg} / \mathrm{m} 3$, modulus elasticity $211 \mathrm{GPa}$, and Poisson ratio 0.35. Material is defined as having isotropic shape. The type of element corresponding to this structure in the 2D Solid 8Node 82 2D analysis model with a uniform thickness.

Mesh selection is made as small as possible by taking into account the maximum value of nodes that can be analyzed by the program. In this study the mesh size taken is $6 \mathrm{~mm}$ (figure 5).

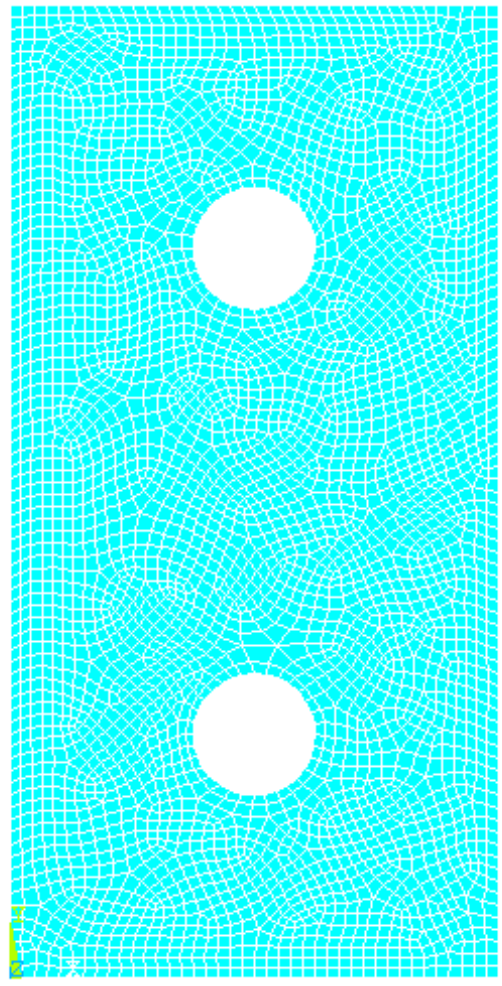

Figure 5. Shape Mesh on model

\section{RESULT AND DISCUSSION}

The load received by the holder plate comes from the weight of the superheater header plus the superheater pipe with a total weight (Q) of 95 tons. Then the amount of load received on each hanger rod is $51.775 \mathrm{kN}$. Because the hanger plate on each hanger rod is 2 pieces, then on each plate will receive $25.88 \mathrm{kN}$.

Based on contact area theory, it is known that the length of half of contact area is $b=0,0047 \mathrm{~m}$. Then the contact area of the plate is $2 \mathrm{~b}$ or equal to $0.0047 \times 2=$ $0.0094 \mathrm{~m}=9.4 \mathrm{~mm}$. The maximum voltage that occurs in the contact area is 560,985 $\mathrm{MN} / \mathrm{m} 2$. The voltage distribution at the contact area lies between lengths of $0.0047 \mathrm{~s} / \mathrm{d} 0.0047 \mathrm{~m}$. The amount of stress distribution in this area is shown in Table 1. 
Tabel 1. Stress distribution on contact area

\begin{tabular}{|r|r|}
\hline \multicolumn{1}{|c|}{$\mathrm{z}$} & $\sigma_{\mathrm{z}}$ \\
\hline 0 & -560.9852 \\
\hline 0.0005 & -554.6914 \\
\hline 0.001 & -536.6298 \\
\hline 0.0015 & -509.0065 \\
\hline 0.002 & -474.7903 \\
\hline 0.0025 & -437.0197 \\
\hline 0.003 & -398.2934 \\
\hline 0.0035 & -360.5359 \\
\hline 0.004 & -324.9879 \\
\hline 0.0045 & -292.3226 \\
\hline 0.005 & -262.8003 \\
\hline
\end{tabular}

The numerical simulation results with the help of Ansys software are shown in Figure 6. Contour color changes show the occurrence of nodal displacement in the specimen.
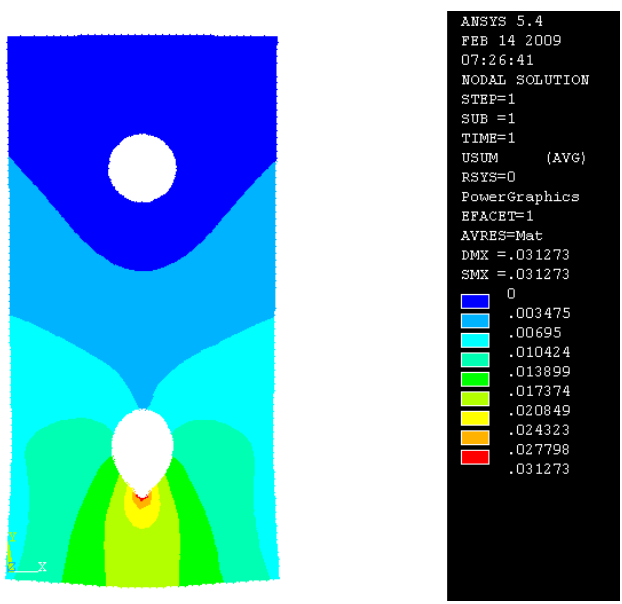

Figure 6. Nodal displacement simulation

Maximum displacement occurs in the contact area. If the maximum area is enlarged (Figure 7), then the magnitude of the displacements at each node is shown in Table 2.

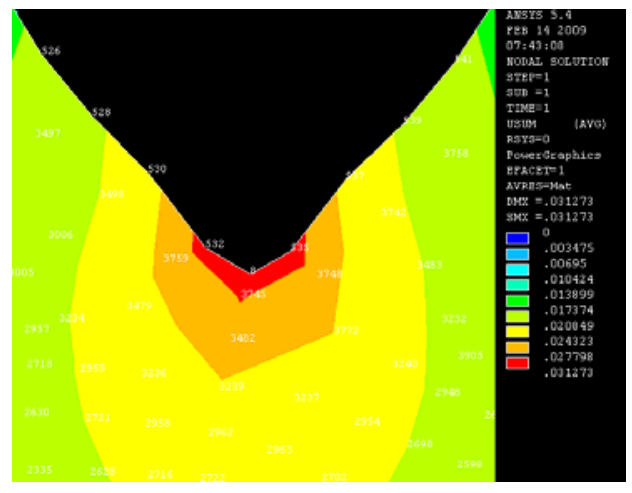

Figure 7. Maximum displacement area

Tabel 2. The value of maximum nodal displacement

\begin{tabular}{|c|c|c|c|r|}
\hline NODE & UX & UY & UZ & USUM \\
\hline 8 & $.26860 \mathrm{E}-05$ & $\begin{array}{c}-.31273 \mathrm{E}- \\
01\end{array}$ & .0000 & $.31273 \mathrm{E}-01$ \\
\hline 532 & $24634 \mathrm{E}-02$ & $\begin{array}{c}-.28965 \mathrm{E}- \\
01\end{array}$ & .0000 & $.29069 \mathrm{E}-01$ \\
\hline 535 & $\begin{array}{c}-.25390 \mathrm{E}- \\
02\end{array}$ & $\begin{array}{c}-.29346 \mathrm{E}- \\
01\end{array}$ & .0000 & $.29455 \mathrm{E}-01$ \\
\hline 3745 & $.64725 \mathrm{E}-04$ & $\begin{array}{c}-.27982 \mathrm{E}- \\
01\end{array}$ & .0000 & $.27982 \mathrm{E}-01$ \\
\hline
\end{tabular}

Maximum stress also occurs in almost the same region. The numerical simulation results are shown in Figure 8. The value of the stress distribution at that maximum region is shown in Table 3.

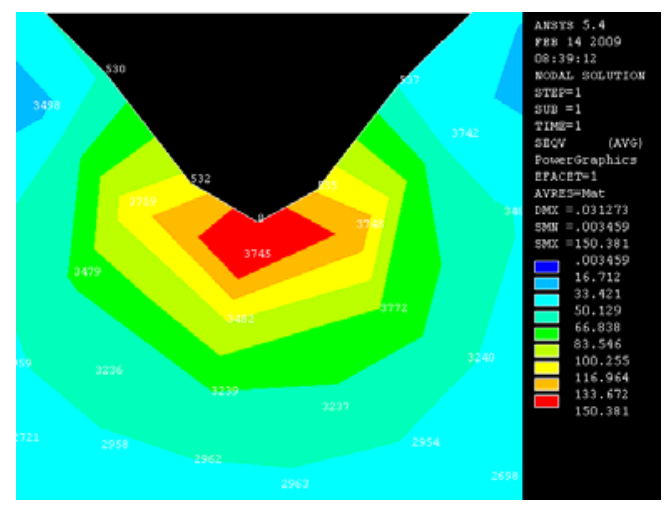

Figure 8. Maximum stress area

Tabel 2. The value of maximum stress distribution

\begin{tabular}{|c|l|l|l|l|l|}
\hline NODE & S1 & S2 & S3 & SINT & SEQV \\
\hline 8 & .00000 & -130.39 & -164.36 & 164.36 & 150.29 \\
\hline 3745 & .00000 & -21.923 & -160.14 & 160.14 & 150.38 \\
\hline
\end{tabular}




\section{Amrinsyah, Numerical Study on Plate Holders Pipe Recovery Boiler Superheater}

\section{CONCLUSION}

Based on the results of the analysis can be seen that the displacement and the maximum voltage occurs in the contact area between the retaining plate and superheater pin. This is due to this area of superheater load directly transmitted through the pins to the retaining plate. Thus, the dampening part is strongly recommended to maintain the stability of the construction.

\section{ACKNOWLEDGMENTS}

Acknowledgments to PT. GAKA Karya Engineering, Pangkalan Kerinci, Riau for good cooperation and facilities so that researchers get the research data and complete the research report well.

\section{REFERENCES}

Tavares, S., Pardal, J., Souza, G., Garcia, P., Barbosa, E., Barbosa, C., \& Filho, I. C. (2014). Study of cracks in the weld metal joint of p91 steel of a superheater steam pipe. Engineering Failure Analysis, 464-473.

Yasniy, O., Pyndus, Y., Brevus, V., Iasnii, V., \& Lapusta, Y. (2016). Lifetime estimation of superheater header. 21st European Conference on Fracture, ECF21 (pp. 840-846). Catania: Procedia.

Barma, M., Saidur, R., Rahman, S., Allouhi, A., Akash, B., \& Sait, S. M. (2017). A review on boilers energy use, energy savings, and emissions reductions. Renewable and Sustainable Energy Reviews, 970-983.
Sankar, G., Rao, A. C., Seshadri, P., \& Balasubramanian, K. (2016). Techniques for measurement of heat flux in furnace waterwalls of boilers and prediction of heat flux. Applied Thermal Engineering, 1470-1479.

Shokouhmand, H., Ghadimi, B., \& Espanani, R. (2015). Failure analysis and retrofitting of superheater tubes in utility boiler. Engineering Failure Analysis, 20-28.

Taler, D., Trojan, M., Dzierwa, P., Kaczmarski, K., \& Taler, J. (2018). Numerical simulation of convective superheaters in steam boilers. International Journal of Thermal Sciences, 320-333. 